\title{
From Theatre History to Canadiana: The Canadian Deposit Collection in the British Library
}

Patrick B. O’Neill

To have a theatre historian address a convention of bibliographers is to recall Dr. Johnson's famous 'dog walking on his hinder legs. It is not done well, but you are surprised to find it done at all.'

It results perhaps from a change in attitude toward Canadian Studies' scholarship that has been growing across the country. Young academics are not satisfied with the superficiality of the research that has gone before and is still occurring today. At a recent editorial meeting for Theatre History in Canada, the complaint was voiced that too many of the investigations over the last twenty years have been journalistic in nature rather than demonstrations of real scholarship. A theatre reviewer reports on a single event whereas a theatre critic searches out its significance and tries to place the play in the context of what has happened before and what will happen in the future. Far too often papers on Canadian Studies' topics have focused, like reviewers, on one event, one novel, one play, one author. We cannot study such things in isolation and achieve any critical understanding of the significance of the work or the person. We cannot flesh out the body, however, without the skeleton. In a researcher's mind, the skeleton of the proposed work is the bibliography one first assembles. Without access to a proper bibliography, the critic is a journalist and the work unsophisticated. Unfortunately, the source books for compiling the bibliography have been lacking in the past.

In 1976 I began a research project which I entitled 'Towards the Corpus of Canadian Drama.' When I undertook the project, researchers had access to nearly I,0oo play titles in the original Brock Bibliography and its Supplement. ${ }^{1}$ From index cards with references to Canadian material which I had piled up while investigating other matters in the field of Canadian theatre history, however, I was certain that Canadian playwrights had produced more scripts than those listed in the Brock Bibliography. Discovering that the Harris collection at Brown University Library alone claimed to

This paper was given at the $4 \mathrm{I}$ st Annual Meeting of the Bibliographical Society of Canada in Quebec City on I 8 June 1986. 
have more than 2,500 Canadian playscripts in its collection, and motivated by the publishing requirement which underlies promotion and tenure, I determined that this collection ought to provide an instant publication by a comparison of its list of Canadian plays and the Brock Bibliography. When I arrived at Providence, R.I., there were instead instant problems.

The librarians at Brown firmly believed that they had 2,500 Canadian scripts. They could not, however, identify which of the 90,000 playscripts in their holdings were Canadian. This collection also contains 28,000 broadsides of poetry and $\mathrm{I} 70,000$ pieces of sheet music, both American and Canadian, with no way to ascertain which items are Canadian.

I stood before their card catalogue and found myself contemplating an interesting research problem. How could I identify the Canadian scripts in their collection? Re-examining the original Brock, I discovered what seemed to me the basic weakness in its methodology. The Brock compilers had written to libraries across Canada for information about their holdings, and had prepared the bibliography from reports of scripts already identified as Canadian and held by libraries in Canada. The problem then was to identify material not labelled Canadian nor held by Canadian libraries. While considering this problem I re-read the introduction to Allardyce Nicoll's bibliography of English drama. ${ }^{2}$ Discovering that he had used the Lord Chamberlain's records to compile his lists of English plays, I turned my thoughts to possible government agencies in Canada that would have lists of Canadian plays. The only possibility that I could imagine was the Copyright Office. The solution might lie in the copyright registers.

I decided, therefore, to approach the Copyright Office in Ottawa and prepare a list of copyright material. But there was weakness in this scheme as well for the period prior to I924. Dramatic material was not eligible for copyright in Canada unless it met the criteria for a published book. With typical Canadian abandon, my thoughts turned southward to the American copyright registers. Finally Dionysius smiled. In its early days, the U.s. Copyright Registers listed the nationality of each author, but more important than this, when material - even unpublished material - was copyrighted in the United States, a copy was sent to the Copyright Office and eventually filed in the Library of Congress. The Copyright Office in Washington thus became a cornucopia of dramatic pieces.

My general methodology thus followed a typical dull, plodding format of standard research: compiling a checklist from the lists available in the Canadian and American copyright registers. Canadians have been accused of approaching life like accountants: in methodology I am undoubtedly guilty of an accountant's mentality. Nevertheless it furnished me with the basic skeleton of the desired corpus; it gave me an entry point from which to examine library holdings. This list was published in two parts in Cana- 
dian Drama and contains over 6,000 titles of Canadian plays. ${ }^{3}$

The next stage of the project was to locate the actual scripts. Beginning in the Library of Congress, I located approximately 950 Canadian playscripts. Through a grant from the Social Sciences and Humanities Research Council of Canada (ssHrcc) and Mount Saint Vincent University, these scripts were microfilmed for my use and eventually they will be available from the Mount library. This collection contains plays by Arthur McKee Rankin, Merrill Dennison, Mazo de la Roche, William Kirby, Morley Callaghan, and others. It also contains some seventy musical comedies by Canadians. ${ }^{4}$

Having finished in Washington, I was then ready to return to the Brown University collection. I undertook a survey which confirmed that they do have over 2,500 Canadian playscripts in their collection. In fact, the collection numbers nearly 3,000, which makes it probably the finest collection anywhere. Using my survey of the Brown collection, I also prepared a list of French-Canadian titles not included in Rinfret's bibliography. ${ }^{5}$ This list of play titles in Brown University, cross-checked to the Canadian and American copyright registers, I submitted for publishing consideration to the Bibliographical Society of Canada. In a letter dated 9 October I979, the editor decided not to publish the list: 'because of the nature of Canadian copyright during the period studied, there is no way of telling which of these "copyright" titles represent an actual book and which is merely a ghost.'

Since I had physically handled the material at Brown, I knew they were not ghosts. But what was a 'ghost'? At Dalhousie Law Library, I was able to read the various copyright laws and determine the nature of these bibliographic ghosts. Prior to I924, only printed materials could be copyrighted in Canada. Since I924, manuscripts could be copyrighted without depositing copies with the Copyright Office. There is no way to ascertain that these materials were in fact written. These then are the potential ghosts. Why someone would pay a registration fee for an unwritten work, I cannot fathom: however, the possibility existed and still does today. It seemed that any list compiled from the copyright registers alone would be questioned, unless I could locate each individual item.

My reading of the copyright legislation had revealed valuable clues as to the locations of more of the published materials. Publishers sent copies of the books to Ottawa with their application for copyright prior to I924and with luck I should be able to find those books in Ottawa. Returning to Ottawa with my completed lists compiled from the copyright registers, I encountered difficulties. I could not find all the material in the National Library, nor in the Library of Parliament. According to my reading of the copyright acts of Canada the material should have been there. 
What exactly does the copyright legislation reveal about the collection of Canadian book material? The first piece of federal copyright legislation was passed in 1868 when Parliament re-enacted the Copyright Act of the Province of Canada as stop-gap legislation to apply in the new Dominion; publishers were required to deposit two free copies with the Minister of Agriculture who kept one in the Copyright Office and deposited the other in the Library of Parliament, which had been established by the purchase of the Legislative Library of the Province of Canada for \$200,000 in I867. The first complete and original copyright legislation in Canada was the Canadian Copyright Act of I875. This act, which was substantially reenacted with some alterations first in the Revised Statutes of I886 and later in the Revised Statutes of 1906, supplied the basis for copyright in Canada between the years I 875 and I924. It granted copyright for twentyeight years from the time of registration to any person living in Canada or any other part of the British Dominions, and recognized the copyright for a similar period of a citizen of any country having an international copyright treaty with the United Kingdom. The impetus for the legislation came from business interests and thus concerned itself primarily with the commercial aspects of printed and published works rather than the right by authorship to a written work. ${ }^{6}$ To register a work and thus obtain copyright under the Canadian law, the person, often the publisher and not the author, had to comply with the following conditions: first, such literary, scientific, or artistic works had to be printed and published, or reprinted and republished in Canada; and secondly, two copies of the book, map, chart, musical composition, photograph, print, cut, or engraving had to be deposited at the Office of the Minister of Agriculture. For paintings, drawings, statuary, and sculpture, a written description of such work could be substituted and sent to the Minister. The Act of 1875 , as had the earlier I 868 Act, instructed the Minister of Agriculture to deposit one copy of the work in the Library of Parliament and to retain the other copy in the Copyright Office. In I895, Section Ten of the Act was amended to require that three copies be sent to the Minister; the third copy was to be forwarded to the Library of the British Museum.

The deposit requirement under the I875 Act and its Amendment of I 895 remained unaltered until the passing of the Act of I92 I. The I92 I Act repealed and superceded all prior copyright legislation in Canada, and, with its various amendments, is the basis of Canadian copyright law today. Sadly, the I92 I Act (which was not proclaimed until I January I924) contained no provision requiring deposit copies of books, in Canada or elsewhere. The Library of Parliament, the Copyright Office, and the British Museum Library all lost their right to free copies of Canadiana on $3 \mathrm{I}$ December I923. This situation obtained until I93I, when a bill was 
passed, 'not intended to revise generally the Copyright Act, but to amend that Act only in so far as is necessary to bring Canadian copyright legislation into conformity with the provision of the Rome Convention of I928.' In addition to its above stated purpose, the amendment included a provision to restore deposits to the Library of Parliament:

The publisher of every book published in Canada, within three months of the publication thereof, shall deliver or cause to be delivered, at his own expense to the Library of Parliament, who shall give a written receipt therefor, two copies of the first edition and two copies of each subsequent edition if such subsequent edition contains additions or alterations either in the letter press or in the maps, prints, or other engravings thereto belonging. ${ }^{7}$

The rationale for this action was explained in a subsidiary note in the amendment: that such copies when deposited, would form the nucleus of a National Library for Canada.

The dream of a National Library, shattered by the Depression and World War II, did not become a reality quickly. Not until I952 did the National Library Act pass through Parliament. Section II of that Act gave the new library the responsibility for the collection and systematic preservation of Canadian material by requiring Canadian publishers to deposit two copies of each publication in the National Library within one week of its release for public distribution or sale.

To summarize, everything copyrighted in Canada prior to I924 or published in Canada after I93 I found its way as deposit material into official libraries. The Acts produced three sets of collections: the Library of Parliament / National Library Collection; the Copyright Office Collection; and lastly, the smallest, the British Museum Collection.

Why then could I not find the material that I sought at the National Library or the Library of Parliament? Unfortunately the Library of Parliament had suffered two disastrous fires. The first fire in I916 began in the reading room of the Library and eventually destroyed the rest of the Parliament Buildings. The Report of the Joint Librarians indicates that everything in the reading room was destroyed, much of it by the water thrown upon the burning buildings. A second fire began in the dome of the Library of Parliament in I953 and water damage again caused most of the destruction as it cascaded down upon the collection. The collection was not totally destroyed by these two fires, but certainly it was seriously depleted. Michel Theriault of the National Library, in charge of the Canadiana I867-I900 Project, and Maria Bryce, Music Division, National Library have both admitted that the National Library does not contain a full set of deposit materials. 
Unable to locate the materials in the National Library, I decided to trace the Copyright Office Collection. The history of the Copyright Office Collection, consisting of the second deposit copies received after I 868 is better documented. Failing to determine what had happened to the collection by interviewing staff at the Copyright Office, I turned the problem over to my then Member of Parliament, the Hon. Robert Stanfield. Within a day his staff had succeeded in tracing a memorandum dating from 1937 which stated that, because of its impending removal to new premises, the Copyright Office requested direction on the disposition of its collection of deposit material, since the new offices lacked the necessary storage space. Forces of Continentalism outweighing Nationalism in I938, the Committee of the Privy Council determined that few of the 'several thousands of volumes of books, catalogues, periodicals, pamphlets, sheet music, maps' etc. had any value. An Order-in-Council, signed by Lord Tweedsmuir and Prime Minister MacKenzie-King, ordered that the material be offered for selection to the Secretary of State Library and that the Copyright Office dispose of what remained. The Secretary of State Library observed shortly thereafter that 'one hundred and fifty-five books of prominent Canadian statesmen and the History of Canada were obtained from the Copyright Office, together with some sixty volumes of Canadian fiction.' A search of the Public Records Office did not reveal further correspondence on this subject; the remaining 50,000 odd pieces were presumably destroyed. ${ }^{8}$

Being unable to find printed copies of playscripts published in Canada prior to 1924 in the National Library, I visited the British Library for the first time in 1979 and located I I 4 plays written prior to I 924 and not available in Canada. While there, I discussed the fact that all the material published in Canada between I895 and I924 was deposited in the British Library, and asked if there were an easy way to identify the material. The staff I contacted did not believe that the British Library had the material. A week before I was to return to Canada, however, my query was relayed to Philip Harris (then Head, West European Branch), who had been with the Library for over forty years.

Mr. Harris knew nothing of the Canadian material, but remembered that copyright deposits had come from various Commonwealth countries up until the I96os. Intrigued by my question, he went himself to the office of a colleague who had retired in I968 and located in that office a set of volumes of material received in the British Library from various British Dominions around the world, including an eight volume set entitled 'Canadian Copyright Lists.' These lists were brought to me; they indicated nearly roo percent receipt of the material copyrighted in Canada between I895 and I924. The British Library collection of Canadian copyright deposit material, therefore, is the most complete, for both English and 
French published materials, for the period between I 895 and I924.

You may be interested to know why the British Library possesses this collection of Colonial works. The story begins as so many do in the British Library, with Panizzi, who lobbied for the deposit requirement of Colonial material. The Imperial Copyright Act passed at Westminster in 1842 required Colonial printers to deposit a copy of all their publications with the British Library. Although this material was desired by the British Library, the staff had no effective way of implementing the requirement and as a result the material was never sent.

In 1886 , an Imperial Act removed the requirement of copyright deposit copies from all Colonial publishers including the self-governing Dominions. Since Imperial legislation could not guarantee Colonial deposits, the British Museum now looked to diplomatic channels in the various Dominions as a means of assuring transmission of such materials. In I889, an amended Canadian Copyright Act had passed through Parliament but had failed to receive Royal Assent. During the considerable discussion in England and Canada that followed, the proposed bill came to the attention of the Trustees of the British Museum. On their behalf, E. Maude Thompson, then Director of the British Museum, wrote to the Marquess of Ripon at the Colonial Office requesting that he 'keep the interests of the British Museum in view in the course of the negotiations with the Canadian Government' and 'that, if the Canadian Government obtain any realization of copyright regulations in their favour, they should undertake on their part to comply with the law as regards the deposit of books in the British Museum. ${ }^{9}$ The Marquess of Ripon forwarded the request to the Earl of Aberdeen, then Governor-General of Canada, and asked that he urge the Canadian government to deposit copies in the British Library.

Although the 1889 Act failed to receive Royal Assent, Canada's Parliament did agree that works published in Canada should be part of the British Museum's Library collection. An I895 amendment to the I875 Canadian Copyright Act directed that three copies of each work be deposited with the Minister of Agriculture - the third copy to be deposited with the British Museum. The rationale motivating the Canadian legislators to require a third copyright deposit copy for the British Museum Library was, according to the Report of the Privy Council, that it 'would be the means of introducing the works of Canadian authors to the large and influential class of readers who frequent the library.' In actuality it was probably a political move to gain concessions from the British authors and British government who had opposed the proposed I 889 Canadian copyright legislation.

Returning to Canada with this information, I allowed myself to be sidetracked into the preparation of the 'Canadian Copyright Lists' in the Brit- 
ish Library for use by Canadian academics. I visited with Norman Horrocks and John Ettlinger of Dalhousie and asked what could be done to make this material more accessible to Canadian academics. In I982, a ssHRCC grant was awarded under the Canadian Studies Research Programme. I went to England for my I982-83 sabbatical, John Ettlinger agreed to supervise the project during his sabbatical in $1983-84$, and Norman Horrocks undertook to publish the lists in the Dalhousie Library School Occasional Paper series. John Ettlinger worked on the project during his sabbatical year, but has since resigned, having decided to take early retirement from Dalhousie and to spend his research time on Children's literature. The project has been aided by Margaret Cooter and Barbara James, both graduates of Dalhousie Library School, who have worked in the British Library searching for the materials.

What then is the current state of the project? And how have we proceeded thus far? We prepared an index card for each item registered with the Copyright Office in Ottawa and checked these against the British Library's 'Canadian Copyright Lists' which indicates materials received from Canada for the period between 1895 and 1924 . If an item was not in fact received in the British Library, we indicated that on the card and did not search for it further. We separated the remaining cards into genres to facilitate the search. Over the past three years, we have searched the British Library Catalogues and shelves for the material. The searching was completed in 1986 and the project is finally winding down. There will be seven publications of various genres and I shall talk about those individually.

Volumes I and II deal with the material held by the Map Library: Volume I with maps generally, and Volume II with a particular type of map known as an insurance plan. ${ }^{10}$ These were prepared first for two reasons. The Map Library is the only section of the British Library that completely catalogued all the Canadian copyright deposit material and the Map Library holds a small number of items to be checked - some I,000 maps and $\mathrm{I}, 700$ insurance plans. We could input this material into the computer and ready it for publication with comparative ease and discover the problems that would confront us in the process.

Of the two publications, the more important for Canadian studies is undoubtedly the insurance plans. Robert J. Hayward, in his study of the fire insurance plans in the National Map Collection, ${ }^{11}$ which details the holdings of the Public Archives in Ottawa, states that these are the most sought after maps in their collection. Approximately I 50 copies of these plans were printed by the Charles E. Goad Company and lent to insurance companies with the understanding that they be returned when an updated plan was prepared. Fire insurance plans are maps, or a set of maps, of a 
community showing in detail, by means of colour and symbol, the character of the outside and inside construction of buildings, passages, fire walls, openings in walls, height, and occupancy or use of the building or groups of building. The collection of plans in the British Library numbers over I,400. Louis Cardinal and Robert Hayward of the Public Archives estimate only 30 percent of these exist in Canada. For example, of the 22 I plans and revisions for communities in Saskatchewan drawn by Goad throughout the period I895 to I917, the Saskatchewan Archives holds 7, the Public Archives holds 25, and the British Library 202. Maps in the Public Archives do not constitute part of the missing copyright material; since publishing the list I have discovered why. In I92I, the Goad Company wrote to the Library of Parliament and to the Copyright Office and asked that the copies they had submitted over the years be returned to them, which they were. ${ }^{12}$ The Goad plans were systematically destroyed by the Charles Goad Company so they could not be copied by another company and sold. No copyright deposits will ever be found in the National Library holdings of the Goad plans because the originals were removed at the company's request. Copies held by the National Library and Public Archives have been acquired later through private sources.

Volume III, the next publication, is a two part set dealing with directories: Part I was published in I986 and details city and area directories; Part 2, as yet unpublished, contains telephone directories and miscellaneous professional directories. ${ }^{13}$ After examining Part I Dorothy Ryder, who published a Checklist of Canadian Directories in I979, wrote that she had gone through the bibliography quite thoroughly and found many directories not recorded in her checklist, 'such as those for the city of Sherbrooke.' In addition, our publication includes street guides and rural mail directories that she had not included because only two or three of them had been reported to the Union Catalogue. ${ }^{14}$ Personally, I look on our publication as an appendix to Ryder's work, and of primary importance to people working on Canadian Studies in England. The importance of the British Library collection is the access it provides to a large number of directories in one location. Part 2, detailing telephone and business directories, will be welcomed by various researchers, but, perhaps, will be most useful to people doing genealogical research or local history.

The fourth volume being prepared is devoted to sheet music. Because it details II,327 pieces of sheet music copyrighted in Canada between the period of 1895 and I924, this work will, in fact, appear in a number of parts. Perhaps as much as 60 percent of this is American music reprinted in Canada, but as a person interested in the cultural milieu of Canada, that tells me a great deal about the subservience of Canadian culture to American. Of the truly Canadian music, the National Library indicated that 55 per- 
cent to 60 percent of the music is not available in any holding in Canada. This means that we must re-evaluate the work on music history in Canada. For example, there are over 200 pieces of music in the British Library collection devoted to, or inspired by, the Boer War, but the Canadian Encyclopedia of Music states that there are only 25 pieces of music relating to the war. ${ }^{15}$ The conclusions people have drawn regarding the patriotic music of the Boer War era may be correct, but since only I 2 percent of the now available corpus was examined, their conclusions must be evaluated again.

The work we have prepared complements the Complete List of Canadian Copyright Musical Compositions (Entered from 1868 to January 19th, 1889) Compiled from the Official Register in Ottawa (n.p., r 889) which was described by the Canadian Encyclopedia of Music as 'a unique example in Canada of a bibliography based on a copyright list. ${ }^{16}$ The National Library has prepared cards for the music published and copyrighted in Canada between I9 January I 889 and the early I90os. The work has never been published but is available for consultation in Ottawa. We have completed a list of music copyrighted in Canada between I895 and I924 which duplicates and greatly extends the period that the National Library covered. This means that a much fuller bibliography of all music published in Canada between I 868 and I924 will soon be available. People doing the history of dance or music in Canada will have an opportunity to derive more valid assumptions from the evidence than ever before in the past.

The fifth volume will be devoted to photographs. Of all the materials discovered in the British Library, the photographs have most captured the attention of the public, and certainly I have received considerable correspondence regarding them. The list of photographs has been inputted and is ready for publication at a later date. It is not a great collection of photographs when compared to that held by the Public Archives of Canada, but it should provide information to cultural historians, since these were the photographs deemed to warrant commercial protection at the time of their production. ${ }^{17}$

The final work in the set will detail all the other material not covered in the first five volumes. Primarily, this is book material. As such, it will cover the same material that appears in the Tod and Cordingly bibliography ${ }^{18}$ but will list many additional items. Tod and Cordingly included only that material containing at least fifty pages, our list includes single sheets of poems, journals, articles reprinted from newspapers, et cetera, as well as books.

The significance of the collection in the British Library is not that individual items are unique, but that a collection representing much of the 
output of Canadian publishers for the period between I895 and I924 was regularly received and is housed complete in one library. Undoubtedly the collection will prove beneficial to scholars in all areas of Canadian Studies in the future. The corpus of Canadian material will be greatly expanded by the checklists we have been preparing. The results will probably be the eventual re-evaluation of the period between 1895 and 1924 in Canadian studies, undertaken by a new generation of academics. In my estimation, their discoveries will greatly change the manner in which we see ourselves. The Symonds Report of 1999 will be a very different document.

My own plan is simply to complete the input of the last volume in the summer of 1987 and then to return to the study of Canadian theatre history and make an attempt, at least, to join the new generation of Canadian scholars.

Recently, a friend asked me what I was doing in the way of research because she had not seen any theatre publication from me. This disturbed me, but I take solace from Allardyce Nicoll who wrote, in A History of Late Nineteenth Century Drama 1850-1900,

I am fully aware of the fact that such a hand-list as is given here, with no adequate guides for assistance, must inevitably have errors and omission - yet it has seemed to me that, worthless though many of the dramas are and though the hand-list may be imperfect, such an attempt at a cataloguing of the total dramatic productivity of the time was necessary to serve as the guide that I myself found lacking and to enable others working on this period to have at least some general conspectus of the entire field. This having been done, later workers may fill in such gaps as I have left and correct mistakes. ${ }^{19}$

I realize that errors and gaps abound in my studies as well, but a new generation of scholars now exists who will 'fill in such gaps as I have left and correct mistakes.'

NOTES

I The Brock Bibliography of Published Canadian Stage Plays in English, 1900-1972 (St. Catharines: Brock University, 1972) and The Brock Bibliography of Published Canadian Plays: Supplement (St. Catharines: Brock University, I973).

2 Allardyce Nicoll, A History of English Drama, 1660-1900, 6 Vols. (Cambridge, England: The University Press, I946-1955).

3 Patrick B. O'Neill, 'A Checklist of Canadian Dramatic Materials to I967,' in Canadian Drama / L'Art dramatique canadien, 8: no.2 (1982), pp. 173-303 and 9: no.2 (I983), pp. 369-506.

4 Catalogue of the Canadian Drama Collection in the Library of Mount Saint Vincent University (Halifax: Mount Saint Vincent University, I984).

5 Edouard de Rinfret, Le Théàtre canadien d'expression française: répertoire analytique des origines à nos jours, 4 vols. (Montréal: Leméac, 1975-78). 
6 As Sir Daniel Wilson, President of the University of Toronto, pointed out in I892: 'It is treated as a mere question between English and Canadian printers and publishers; as though the 'Idylls of the King' ... were the work of the type-setters.' See 'Canadian Copyright,' Proceedings and Transactions of the Royal Society of Canada for the Year 1892, Section II (Ottawa, I 893), pp. 3-I 8.

7 'Copyright Amendment Act, I93 I.' s.C. I93 I, C. 8.

8 Information supplied by Barbara MacDowell, Administrative Assistant to the Hon. Robert Stanfield, I977.

9 Parilamentary Papers, $1895,1 \times x, 90$.

Io John R.T. Ettlinger and Patrick B. O'Neill, A Checklist of Canadian Copyright Deposits in the British Library 1895-1923: Volume I - Maps (Halifax: Dalhousie University School of Library Service, I983) and Patrick B. O'Neill, A Checklist of Canadian Copyright Deposits in the British Library 1895-1923: Volume IIInsurance Plans (Halifax: Dalhousie University School of Library Service, 1984).

I I Robert J. Hayward, Fire Insurance Plans in the National Map Collection (Ottawa: National Map Collection, 1977).

I2 This information is contained in the Goad Papers held by The University of Western Ontario and was supplied to me in correspondence from Edward Phelps, Librarian, Regional Collection, The University of Western Ontario.

I 3 John R.T. Ettlinger and Patrick B. O'Neill, A Checklist of Canadian Copyright Deposits in the British Museum 1895-1923: Volume III, Part I - City and Area Directories (Halifax: Dalhousie University School of Library Service, I985). Part II will be available in the fall of 1987 .

I4 Dorothy E. Ryder, Checklist of Canadian Directories, 1790-1950 / Répertoire des annuaires canadiens, 1790-1950 (Ottawa: National Library of Canada, I979). Correspondence dated i 5 January 1987.

I5 Helmut Kallman, Giles Potvin, and Kenneth Winters, Encyclopedia of Music in Canada (Toronto: University of Toronto Press, 1981), p. 986.

I6 Encyclopedia of Music, p. 84 .

I7 Patricia Pierce used our computer list to compile her book, Canada: The Missing Years 1895-1924 (Don Mills: Stoddart, I985) which is a selection of the photographs we located in the British Library.

I 8 Dorothea D. Tod and Audrey Cordingley, A Checklist of Canadian Imprints, 1900-1925. Catalogue d'ouvrages imprimés au Canada (Ottawa: King's Printer, 1950).

I9 Allardyce Nicoll, A History of Late Nineteenth Century Drama 1850-1900, 2 Vols. (Cambridge, England: The University Press, I946), I, p. ix. 